\title{
The expression of aromatase, estrogen receptor $\alpha$ and estrogen receptor $\beta$ in mouse Leydig cells in vitro that derived from cryptorchid males
}

\author{
M. Kotula-Balak, M. Gancarczyk, J. Sadowska, B. Bilinska \\ Laboratory of Endocrinology \& Tissue Culture, Institute of Zoology, Jagiellonian University, Kraków, Poland
}

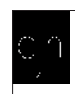

(C2005, European Journal of Histochemistry

A broad expression of aromatase and estrogen receptors (ERs) in the testis suggests an important role for estrogens in regulating testicular cell function and reproductive events. The aim of the present study was to show whether Leydig cells in vitro isolated from cryptorchid testes of two inbred strains of mice, KE and CBA, are a site of estrogen synthesis. Using immunocytochemistry, aromatase, estrogen receptor . $(E R \alpha)$, and estrogen receptor $\beta(E R \beta)$ were localized in cultured Leydig cells. Immunoreactive aromatase was found in the cytoplasm of control Leydig cells and those isolated from cryptorchid males, however the intensity of immunostaining was different, being stronger in Leydig cells deriving from cryptorchid mice. The strongest aromatase immunostaining was found in cryptorchid-KE Leydig cells. Strong immunoexpression of $E R \alpha$ was detected in the nuclei of both KE-and CBA-Leydig cells. The intensity of ER $\alpha$ immunostaining was stronger in cultured cells deriving from cryptorchid testes. $E R$, immunoexpression was detected predominantly in KELeydig cells. Control CBA-Leydig cells were negative for ER, or the result was inconclusive, whereas in cryptorchid CBALeydig cells a weak immunostaining was present in their nuclei. Western blot analysis confirmed the results obtained by immunocytochemistry. In KE- and CBA-Leydig cells aromatase as a band of $55 \mathrm{kDa}$ protein was present, whereas $\mathrm{ER} \alpha$ molecular weight was $67 \mathrm{kDa}$ on Western blots. No band was detected for ER $\beta$. Radioimmunological analysis revealed that androgen and estrogen levels secreted by Leydig cells in vitro were strain-dependent. Additionally, in KE-Leydig cells that derived from cryptorchid mice estrogen level was distinctly higher in comparison with that of the respective control.

Key words: aromatase, estrogen receptors, cryptorchidism, Leydig cells, in vitro

Correspondence to: Prof. Barbara Bilinska, Institute of Zoology, Jagiellonian University, Ingardena 6, 30-060 Kraków, Poland. Fax \# +48-12-634-07-85, e-mail: bbili@zuk.iz.uj.edu.pl

Paper accepted on ???? ?, 2005

European Journal of Histochemistry 2005; vol. 49 issue 1 (Jan-Mar):???-???
$\mathrm{D}$ ata obtained from the studies on aromataseand estrogen receptor gene knockout mice (ArKO, $\alpha E R K 0)$ point at an essential physiological role of estrogens in male fertility, however estrogens may also exert a deleterious effect on testicular cell function (Rosenfeld et al., 1998; Couse and Korach, 1999; 0'Donnell et al., 2001; Mahato et al., 2001). Estrogen action, like that of other steroid hormones, is mediated by specific intracellular receptors in target cells. It has been established that besides classical estrogen receptor $\alpha(E R \alpha)$, novel receptor termed $\beta$ (ER $\beta)$ exists. In species studied to date two types of ERs exhibit different tissue localization pattern and the level of expression. Several studies have documented the presence of estrogen receptors $\alpha$ and/or $\beta$ within the same tissue, which suggests that estrogen action could be mediated either by ER $\alpha$ or ER $\beta$. Involvement of both ERs in the regulation of one cell function is also possible (Sharpe, 1998; Kuiper et al., 1998; 0’Donnell et al., 2001). The fact that both ER $\alpha$ and ER $\beta$ have been found in numerous mammalian species suggests that selective effects of estrogens may depend on promotors that are differentially responsive to $E R \alpha$ and ER $\beta$ (Jefferson et al., 2000).

Identification of the sites of expression of ER $\alpha$ and $E R \beta$ in the testis is essential to elucidate the role of estrogens in testicular physiology (Hess et al., 1997, 2001; Saunders et al., 1998; Durkee et al., 1998; Van Pelt et al., 1999; Bilinska et al., 2000, 2001; Kotula-Balak et al., 2003). In humans, differential expression pattern of ERs in the testis has been found to be analogous to that seen in the ovary. In the latter, ER $\beta$ immunostaining was found in the nuclei of granulosa cells and germinal epithelium cells, the ER $\alpha$ occurred in theca cells whereas in the testis, ER $\beta$ immunoexpression was detected in the nuclei of Sertoli, Leydig, and germ cells while ER $\alpha$ was restricted to Leydig cells. All together these data indicate that there is a celland species-specific localization for each of the ERs. 
The presence of aromatase and ERs in mouse, rat, and bank vole testicular tissue was demonstrated by means of immunohistochemistry ( Nitta et al., 1993; Janulis et al., 1996; Saunders et al., 1998, 2001; Levallet et al., 1998; Bilinska et al., 2000, 2001), in situ hybridization (Van Pelt et al., 1999; Pelletier et al., 2000; Mowa and Iwanaga, 2001), and RT-PCR (Levallet and Carreau, 1997; Carreau et al., 1999; Makinen et al., 2001). Recently, aromatase immunoexpression (Rago et al., 2003) and aromatase mRNA (Lambard et al., 2003) have been detected in human ejaculated spermatozoa. However, only limited information is available about aromatase gene expression or the specific localization of aromatase and estrogen receptors in cultured Leydig cells (Gennisel et al., 2001; Papie et al., 2002).

In KE and CBA mice, differences in relation to fertility parameters have been studied for many years (Krzanowska, 1970) and described in detail in her further reports (Styrna and Krzanowska, 1995; Krzanowska and Bilinska, 2000; Styrna et al. 2002). A site of androgen aromatization both in control and cryptorchid testes of those mice has recently been reported (Bilinska et al., 2003). Therefore, for the present study we used the testes of KE and CBA mice as a source of Leydig cells in vitro. The goal of this study was twofold. First, to establish a cell culture model of Leydig cells that derived from cryptorchid mice. Such a model would be useful for further analysis of pathophysiology of cryptorchid testis. The second, to check whether the hormonal profiles and ER expressions in Leydig cells in vitro undergo changes during culture. Finally, in the light of our earlier paper (Bilinska et al., 2003) it was important to show whether in Leydig cell in vitro the alterations caused by cryptorchidism are rather involved in testosterone secretion or testosterone metabolism. For this purpose aromatase, ER $\alpha$, and ER $\beta$ were localized immunohistochemically in the cell cultures and the presence of the proteins was checked on Western blots. Additionally, testosterone and estradiol secretion by cultured Leydig cells was determined radioimmunologically in the culture media.

\section{Materials and Methods}

\section{Animals}

Induction of cryptorchidism in mature male mice from $K E$ and $C B A / K w$ inbred strains has been described previously in detail (Krzanowska and Bilinska, 2000). Experiments were performed in accordance with Polish legal requirements under the license provided by the Commission of Bioethics at the Jagiellonian University. All mice were given commercial pelleted diet, water ad libitum, and maintained under $12 \mathrm{~h}$ light-dark cycle. Testes from KE and CBA mice, both control and cryptorchid, served as a source of Leydig cells.

\section{Cell isolation and culture}

Six decapsulated testes from mice of each strain were used for the preparation of Leydig cell suspension. Briefly, the crude Leydig cells were obtained by trypsin digestion ( $2 \times 5$ min; $0.25 \%$ trypsin in PBS), then they were serially sieved through $156 \mu \mathrm{m}$ and $74 \mu \mathrm{m}$ pore-size steel meshes (US Standard Sieve ASTME, Dual MFG Chicago). The supernatant was collected and centrifuged at 180x $g$ for $5 \mathrm{~min}$, then the cell pellet was subjected for purification by centrifugation on continuous 10$90 \%$ (v/v, $50 \mathrm{~mL}$ ) Percoll gradient (Pharmacia, Uppsala, Sweden) using the method described by Schumacher et al. (1978) with our own modifications. After centrifugation, $800 \times$ g, for $25 \mathrm{~min}$ at $4^{\circ} \mathrm{C}$ as low temperature significantly prevents cell aggregation, the cell band containing Leydig cells was collected, washed, and centrifuged once or twice at room temperature with low-speed ( $90 \times \mathrm{g}$ for $10 \mathrm{~min})$. Finally, the cells were washed twice in PBS, resuspended in culture medium; Medium 199 supplemented with $3 \%$ calf serum, L-glutamine and sodium bicarbonate, containing penicilin ( 120 i.u./mL). Average inoculum contained $1 \times 10^{5}$ cells $/ \mathrm{mL}$ of culture medium. The purity of the cells was about $84-86 \%$ as it was checked by a histochemical test for $\Delta^{5}, 3 \beta$-hydroxysteroid dehydrogenase $\left(\Delta^{5}, 3 \beta-H S D\right)$ activity. Viability of the cells assessed by trypan blue exclusion test was <93$95 \%$. The Leydig cells were cultured for 48 hours at $37 \Delta \mathrm{C}$ in a humidified atmosphere of $5 \% \mathrm{CO}_{2}$ in air, in 24-well-culture dishes (Nunc, Kalmstrup, Denmark). The cell cultures were performed in triplicate. For immunocytochemistry each well was closed with a round coverslip of appropriate diameter. The culture media were collected and stored at $-20^{\circ}$ for hormone determinations.

\section{Immunocytochemistry}

Cultured Leydig cells were processed for the visualization of aromatase and ERs using the immuno- 
cytochemical technique described previously (Bilinska et al., 2000). After fixation with 2\% formaldehyde freshly prepared from paraformaldehyde for $15 \mathrm{~min}$ and permeabilization with $0.1 \%$ Triton X-100 in Tris-buffered saline (TBS; $0.05 \mathrm{M}$ Tris- $\mathrm{HCl}$ plus $0.15 \mathrm{M} \mathrm{NaCl}, \mathrm{pH} 7.6$ ) for 3 min the cells were incubated overnight at $4^{\circ} \mathrm{C}$ in a humidified chamber in the presence of primary antibodies: 1) a rabbit polyclonal antibody against human P450 aromatase (1:400; a kind gift from Dr. Y. Osawa), 2) a mouse monoclonal antibody against human ER $\alpha$ (1:100; ER $\alpha-1 D 5 ;$ Dako, Glostrup, Denmark), and 3) a rabbit polyclonal antibody against rat ER $\beta \quad(1: 100 ;$ PA1-310; Affinity BioReagents, Golden CO, USA). Next, biotinylated secondary antibodies, horse anti-mouse or goat anti-rabbit IgGs (1:400; Vector, Burlingame CA, USA), were applied, respectively. All antibodies were diluted in TBS. Finally, avidin-biotinylated horseradish peroxidase complex (1:100; Dako) was used. After each step of staining procedure the cells were carefully rinsed with TBS. Peroxidase activity was visualized using $0.01 \%$ hydrogen peroxide, $0.05 \%$ diaminobenzidine, and $0.07 \%$ imidazole (Sigma Chemical Co., St Louis MO, USA) dissolved in TBS. Experiments were repeated three times. For negative control, Leydig cell cultures were incubated in the presence of irrelevant IgGs instead of primary antibodies. The cells were examined with a Leica DMR microscope (Germany) using Nomarski interference contrast.

\section{Western blot analysis}

Cultured Leydig cells from mice of both strains served as the source of protein for immunoblot analysis. The cells were homogenized in $50 \mathrm{mM}$ Tris-EDTA; pH 7.5 as described previously (KotulaBalak et al. 2004). Protein concentration was determined with Bradford reagent (Bio-Rad Protein Assay; Bio-Rad Laboratories GmbH, München, Germany), using bovine serum albumin as a standard. Protein aliquots (50 $\mu \mathrm{g}$ each) were mixed with an equal volume of $2 \times$ concentrated sample buffer (Bio-Rad) and denaturated by boiling for $3 \mathrm{~min}$. Then, the samples were run on discontinous polyacrylamide gels ( $5 \%$ stacking and $10 \%$ separating gel) under reducing conditions. After electrophoresis, the separated proteins were electrophoretically transferred to nitrocellulose membranes at $90 \mathrm{~mA}$, overnight at $4^{\circ} \mathrm{C}$. Then, they were washed again overnight with TBS (the same as for immunocytochemistry) containing 5\% non fat dried milk. Afterwards, the membranes were incubated in the presence of the same antibodies as for ICH. Antibodies were diluted 1:1000 in TBS. Next, the membranes were rinsed to remove the unbound antibody and incubated with a horse anti-mouse or goat anti-rabbit IgGs (1:600; Vector Lab., Burlingame, CA, USA) coupled to horseradish peroxidase $(1: 1000)$ for $1.5 \mathrm{~h}$ at room temperature. Bands were visualized by incubation in TBS containing DAB $(0.5 \mathrm{mg} / \mathrm{mL})$, and $0.3 \% \mathrm{H}_{2} \mathrm{O}_{2}$. Porcine granulosa cell culture was used as the positive control. In order to check repeatability of these findings 3 separate analyses were performed. As a standard, Kaleidoscope Standard proteins (Bio-Rad Lab., Richmond, CA, USA) were used.

\section{Steroid analysis}

Leydig cell culture media were analyzed for androgen and estrogen contents using appropriate radioimmunoassays as described in detail (KotulaBalak et al. 2004). Androgen concentrations were determined using $\left[1,2,6,7,-{ }^{3} \mathrm{H}\right]$-testosterone (The Radiochemical Centre, Nycomed Amersham, Buckinghamshire, England), specific activity, 81.0 $\mathrm{Ci} / \mathrm{mmol}$, as tracer and an antibody raised in rabbit against testosterone-3-0-carboxy methylo-oximebovine serum albumin (BSA), whereas estrogens were assessed using $\left[2,4,6,7,-{ }^{3} \mathrm{H}\right]$-estradiol (The Radiochemical Centre, Nycomed Amersham), specific activity, $86.0 \mathrm{Ci} / \mathrm{mmol}$, as tracer and an antibody raised in rabbit against estradiol-17 $\beta-6$ oxime-BSA. Androgen antibody cross reacted with $5 \alpha$-androstane-17 $\beta$-01-3-one (100\%), with dihydrotestosterone $(20.8 \%)$, with androstendione, $(15.6 \%)$, with androsterone $(7.4 \%)$, and with dehydroepiandrosterone $(3.5 \%)$. Eight other steroids cross reacted for less than $0.01 \%$. Coefficients of variation within and between assays were $7.3 \%$ and $9.7 \%$, respectively.

The specificity of the antiserum for estrogen was high. The antibody cross reacted with estradiol $(100 \%)$, with estrone $(68 \%)$, and with estriol $(2.4 \%)$. Cross reactions for other steroids were below $0.1 \%$. Coefficients of variation within and between assays were $3.2 \%$ and $7.5 \%$, respectively. The lower limit of sensitivity of the assays was 5 $\mathrm{pg} / \mathrm{tube}$. All samples were assayed in duplicates from at least 3 separate experiments. Testosterone levels are expressed in $\mathrm{ng} / 10^{5}$ cells, whereas estradiol levels are expressed as $\mathrm{pg} / 10^{5}$ cells. Statistical 

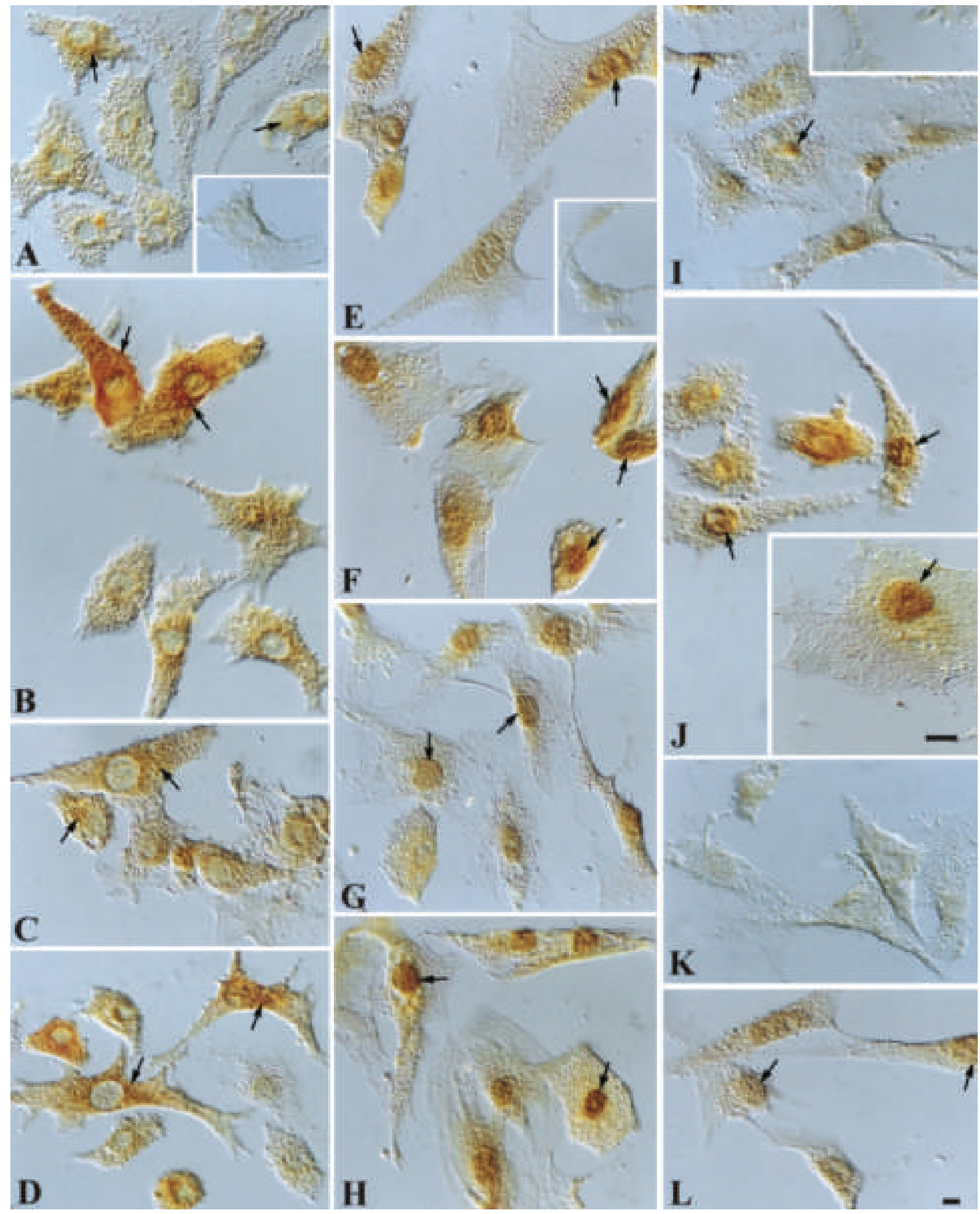

Figures 1. A-L) Immunocytochemistry of Leydig cells in vitro. Leydig cell cultures immunostained for aromatase, ER $\alpha$, and ER $\beta$. Scale bar represents $10 \mu \mathrm{m}$. Immunoreactivity for aromatase in control (A) and cryptorchid (B) KE-Leydig cells as well as in control (C) and cryptorchid (D) CBA-Leydig cells. Positive staining is visible only in the cytoplasm of the cells. Note a stronger immunoreactivity for aromatase in Leydig cells of cryptorchid mice (arrows). Immunoreactivity for ER $\alpha$ in control (E) and cryptorchid (F) KE-Leydig cells as well as in control (G) and cryptorchid (H) CBA-Leydig cells. Only nuclear immunostaining is visible. Note a stronger immunoreactivity for ER $\alpha$ in Leydig cells of cryptorchid mice (arrows). Immunoreactivity for ER $\beta$ in control (I) and cryptorchid (J) KE-Leydig cells. A nuclear immunostaining of ER $\beta$ is visible. Note a stronger immunoreactivity for ER $\beta$ in Leydig cells of cryptorchid mice (arrows), see also a larger magnification (insert in J). No immunoreaction for ER $\beta$ in control CBA-Leydig cells (K), whereas in cryptorchid CBA-cells (L) a weak immunoreactivity in the nuclei is visible (arrows). No immunoreactions are found in the respective negative controls (see inserts in A, E, I). 
evaluation of the data included one-way analysis of variance (with the significance level at $p<0.05$ ) and the Duncan's multiple range test.

\section{Results}

Morphological analysis of isolated Leydig cells prior to culture revealed differences in cell size of more than $60 \%$ of the cells when control cells versus those of the cryptorchid were compared. Leydig cells that derived from cryptorchid mice possessed a larger nuclei than those of the controls. In cultured cells of either control or cryptorchid mice the number of nucleoli was similar (2-3/cell). There were also no differences in the rate of monolayer formation by Leydig cells obtained either from control or cryptorchid mice. All Leydig cells growing in a 48-hourmonolayer system required a similar time to attach and form a confluent monolayer, however, after further $24 \mathrm{~h}$ in culture, Leydig cells that derived from cryptorchid males became fibroblast-like which was not the case with the cells of the controls.

\section{Immunocytochemistry}

Using immunocytochemistry, a specific, cytoplasmic or nuclear immunostaining, however different in its intensity, was revealed in almost all Leydig cell cultures (Figure IA-L).

The immunostaining for aromatase was detected in the cytoplasm of all Leydig cells obtained either from control or cryptorchid males (Figures A, B, C, D). The intensity of aromatase immunostaining was stronger in KE-Leydig cells than in those of CBA (Figures $A, B$ vs $C, D$ ). Moreover, a distinct difference in the staining intensity was observed between Leydig cells that derived from control or cryptorchid mice. Those of cryptorchid males expressed always much stronger staining than those of the

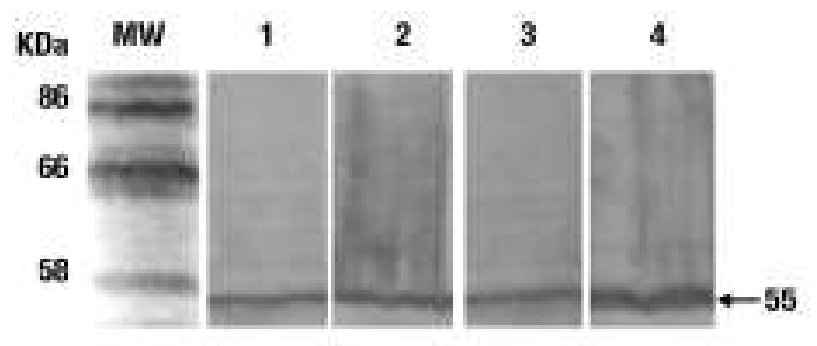

Figure 2. Western-blot analysis of aromatase in control and cryptorchid KE- and CBA-Leydig cells. Lane 1 - control KE-cells; lane 2 - cryptorchid KE cells; lane 3 - control CBA-cells; lane 4 - cryptorchid CBA-cells. Lane MW contains prestained protein standards with molecular weights in $\mathrm{kDa}$. controls (Figures $B, D$ vs $A, C$ ).

Immunostaining for $E R \alpha$ was found in Leydig cell nuclei however, there were no distinct differences between the intensity of the staining in KE and CBALeydig cells (Figures $E, F, G, H$ ). The nuclear immunostaining was always very strong in Leydig cells that were isolated from cryptorchid individuals (Figures $\mathrm{F}, \mathrm{H}$ ).

Positive ER $\beta$ immunoexpression was detected in the nuclei of KE-Leydig cells, predominantly in those deriving from cryptorchid males (Figures I, J). Frequently, individual cells in Leydig cell monolayer expressed various intensity of the staining as did for aromatase and $E R \alpha$ (compare with Figures $B, F$ ). Control CBA-Leydig cells were negative for $E R$, or the result was inconclusive, only non-specific background staining in the cytoplasm was noticed (Figure K), whereas in cryptorchid CBA-Leydig cells a weak immunostaining was detected in the nuclei (Figure $L$ ).

Positive immunostainings for aromatase, ER $\alpha$, and ER $\beta$ were not found when the primary antibodies were replaced by normal horse or goat serum, respectively (see, inserts in Figures $A, E$, and I).

\section{Western blot analysis}

In both KE- and CBA-Leydig cells in vitro, obtained either from control or cryptorchid males, immunodetectable aromatase protein as bands of about $55 \mathrm{kDa}$ (Figure 2, lanes $1,2,3,4)$ and the $E R \alpha$ protein as bands of about $67 \mathrm{kDa}$ (Figure 3, lanes 1,2) were detected. There was no ER $\beta$ protein detected in KEand CBA-Leydig cell cultures (not shown).

\section{Radioimmunological analysis}

Radioimmunological analysis of steroid hormone levels revealed differences between testosterone and estradiol secretion by control and cryptorchid Leydig cells (Figure 4). Strain-dependent differ-

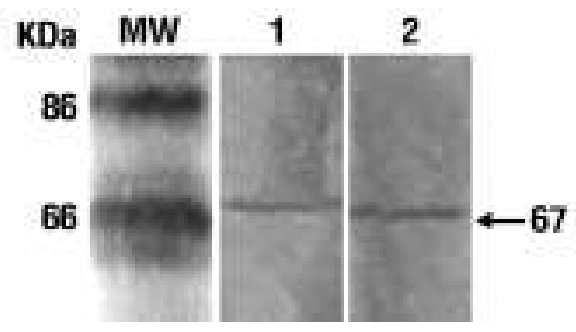

Figure 3. Western-blot analysis of $E R \alpha$ in control and cryptorchid KE-Leydig cells. Lane 1 - control KE-cells; lane 2 - cryptorchid KE-cells. Lane MW contains prestained protein standards with molecular weights in $\mathrm{kDa}$. 

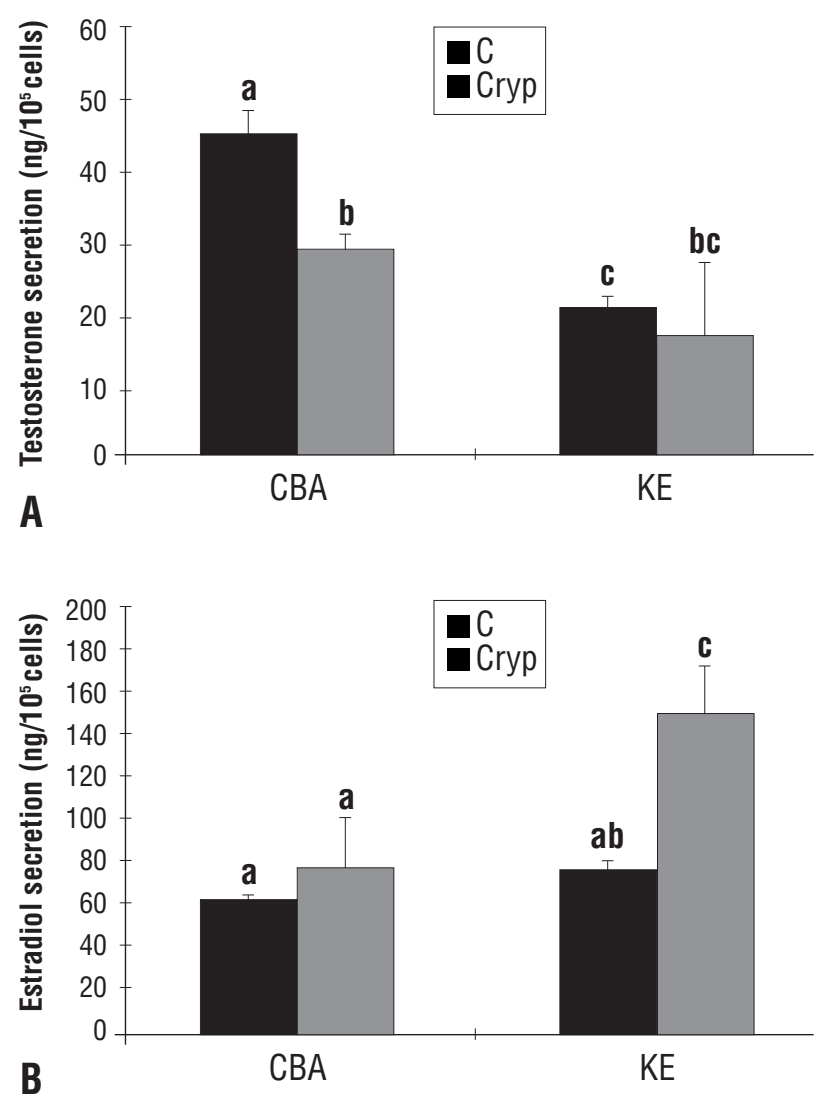

Figure 4. Testosterone (A) and estradiol (B) secretion by cultured Leydig cells of CBA and KE mice obtained either from control or cryptorchid individuals. Means $\pm S D(n=3)$; means without common superscripts $(a, b, c)$ are statistically different $(p<0.05)$.

ences in both hormone levels as well as in estradiol formation were also found. Testosterone levels in CBA-Leydig cells in vitro were much higher than in those of KE. In the cell cultures, estradiol was of various level, being higher in KE-Leydig cells than in CBA-Leydig cells.

In detail, testosterone secretion by control CBALeydig cells was distinctly higher than that of cryptorchid CBA-Leydig cells, whereas in control KELeydig cells testosterone secretion was only slightly higher than that of cryptorchid KE-Leydig cells. The differences were statistically significant at $p<0.05$ (see, Figure 4).

Estradiol secretion in cryptorchid CBA-Leydig cells, was much lower than in those of KE and higher than that of control CBA-Leydig cells ( $p<0.05)$, whereas in cryptorchid KE- cells estradiol secretion was distinctly higher in comparison with that of the controls. Statistical significance was found at the level $p<0.05$ (see Figure 4).

\section{Discussion}

Differences related to the localization of aromatase and estrogen receptors in cultured Leydig cells that have been isolated from control and cryptorchid mice of KE and CBA strains were studied by means of immunocytochemistry and Western blot analysis. Very often, the staining in individual Leydig cells of the same culture was of various intensity that could reflect a functional heterogeneity of Leydig cells in vitro. In all KE- and CBALeydig cell cultures the positive stainings for both, aromatase and $E R \alpha$, were detected. However, the intensity of immunoreaction for aromatase was found to be strain-dependent. The ER $\alpha$ staining was of similar intensity in KE- and CBA-Leydig cells. These results in vitro fit well with our earlier study performed on testicular sections (Bilinska et al., 2003). Moreover, in the present study, straindependence phenomenon was visible in relation to $E R$, expression that was observed in control and cryptorchid KE-Leydig cells. In control CBALeydig cells, either the cells were immunonegative for the $E R \beta$ or non specific, very weak staining in the cytoplasm made definitive immunolocalization inconclusive. Also by Western blot we were unable to detect the presence of $E R \beta$ protein in CBALeydig cells. In the cells isolated from cryptorchid CBA mice a weak ER $\beta$ immunoexpression was localized to Leydig cell nuclei, however in these cells no band for the ER $\beta$ was found. Therefore, we may conclude that in CBA-Leydig cells in vitro only the $E R \alpha$ is responsible for mediating of estrogen action. Comparing the intensity of immunostainings for both ERs in KE-Leydig cells it was clear that the intensity of $E R \beta$ immunostaining was always weaker than that of ER $\alpha$. These results suggest that $E R \alpha$ possibly plays the main role in estrogen-mediated regulation of KE-Leydig cell function, however the additive role of ER $\beta$ can not be excluded. It should be added that the presence of immunoreactive ER $\beta$ observed in KE-Leydig cell cultures is in agreement with previous findings of Saunders et al. (1998) and Rosenfeld et al. (1998) who also detected positive immunoreaction for $E R \beta$ in rat and mouse Leydig cells, respectively. In contrast, our previous studies revealed that bank vole Leydig cells are equipped only with ER $\alpha$ by which the action of estrogen is mediated (Bilinska et al., $2000 ; 2001$ ). This corroborates the study of Fisher et al. (1997) who have shown the expression of 
$E R \alpha$ in rat Leydig cells. Based on other immunocytochemical studies, the predominance of ER $\alpha$ over $E R \beta$ in Leydig cells has also been established (Pelletier and El-Alfy, 2000). On the contrary, according to Saunders et al. (2001), in testicular cells of human and non-human primates, neither Leydig nor other cells express ER $\alpha$ immunoreactivity, however ER $\beta$ immunoexpression have been detected in Leydig, Sertoli, and peritubular cells.

In the present study we also showed differences in the intensity of immunostaining of aromatase and ERs between Leydig cells that derived from control or cryptorchid males. In cultured Leydig cells of cryptorchid mice all immunostainings were always stronger than those in the cells of respective controls. Similar pattern of aromatase expression was previously observed in testicular sections of cryptorchid mice (Bilinska et al., 2003). An increase in immunostaining intensity for aromatase as well as higher estrogen level was also observed in Leydig cells of mouse mutant strain, B10. BR-Ydel in comparison to those that derived from control mice, B10. BR (Kotula-Balak et al., 2004). In transgenic mice with aromatase overexpression that looked like cryptorchid males, Leydig cell hypertrophy and hyperplasia has frequently been found ( $\mathrm{Li}$ et al., 2001). It could be anticipated to our in vitro study, in which the cells prior to culture, isolated from cryptorchid mice were larger in size than those of the respective controls. It should be added that the cells isolated from cryptorchid individuals expressed $3 \beta$-hydroxysteroid dehydrogenase activity, and grew in culture maintaining the features of steroidogenic cells as did the controls, however, after additional $24 \mathrm{~h}$ in culture the shape alterations observed in cryptorchid cells, not in the control cells, could be explained by dedifferentiation of the cells in vitro, that easily loose the hormonal and enzymatic activity.

All together these data are in agreement with the hypothesis that the androgen:estrogen ratio is essential for physiological function of the testis (Sharpe, 1998; Couse and Korach, 1999; 0'Donnell et al., 2001). Moreover, it has been established that a disturbed balance in sex hormone biosynthesis can provoke morphological and functional changes not only in germ cells but also in somatic cells. According to Bergh et al. (1984) it is also possible that disturbances in Leydig cell function result in part from an increase in testicular temperature and in part from changes in testicular microcirculation.
On the contrary, Wu and Murono (1996) reported that a higher temperature stimulates Sertoli cells to produce a growth factor which induces Leydig cell regeneration. This could explain the good condition of Leydig cells that were isolated from cryptorchid testes and then cultured in vitro, as shown in the present study. In these cells we also observed strain-dependent differences in testosterone and estradiol secretion. CBA-Leydig cells in vitro secreted a high amount of testosterone that positively correlates with a very strong $3 \beta-$ HSD activity in cultured Leydig cells as detected earlier histochemically (Godowicz and Bilinska, 1981). In contrast, a low level of testosterone in KE-Leydig cells could be somehow responsible for frequent sperm abnormalities that appear in KE strain of mice (Krzanowska and Bilinska, 2000). On the other hand, a relatively high secretion of estradiol by KELeydig cells correlates well with a high expression of aromatase as detected in these cells and could indicate a strong potential for androgen aromatization in KE-Leydig cells in vitro.

Finally, we can conclude that KE- and CBALeydig cells obtained from cryptorchid mice are able to grow in vitro, and during 48 hours in culture they maintain their steroidogenic features as in vivo. The Leydig cells express the aromatase and are target for estrogens. Estrogenic effects within these cells are principally mediated by the ER $\alpha$. Moreover, cryptorchidism in KE mice is a cause of a distinct increase in testosterone metabolism rather than impairment of testosterone secretion by $\mathrm{KE}$-Leydig cells in vitro.

\section{Acknowledgements}

The authors are grateful to Professor Brian Cook, University of Glasgow, Scotland, for a generous gift of testosterone and estradiol antibodies as well as to Anna Sakiewicz MSc for her help with Western blot analysis. A kind donation of animals from the Department of Genetics and Evolutionism at the Jagiellonian University is highly appreciated.

\section{References}

Bergh A, Damber JE, Ritzen M. Early signs of Sertoli and Leydig cell dysfunction in the abdominal testes of immature unilaterally cryptorchid rats. Int J Androl 1984;7:398-408.

Bilinska $B$, Schmalz-Fràczek $B$, Sadowska J, Carreau S. Immunolocalization of cytochromeP450 aromatase and estrogen receptors $\alpha$ and $\beta$ in bank vole testicular cells. Acta histochem 2000;102:167-81.

Bilinska B, Schmalz-Fràczek B, Kotula M, Carreau S. Photoperioddependent capability of androgen aromatization and the role of 
estrogens in the bank vole testis visualized by means of immunohistochemistry. Mol Cell Endocrinol 2001;178:189-98.

Bilinska B, Kotula-Balak M, Gancarczyk M, Sadowska J, Tabarowski $Z$, Wojtusiak A. Androgen aromatization in cryptorchid mouse testes. Acta histochem 2003;105:57-65.

Carreau S, Genissel C, Bilifska B, Levallet J. Sources of oestrogen in the testis and reproductive tract of the male. Int $J$ Androl 1999;22:211-23.

Couse JF, Korach KS. Estrogen receptor null mice: what have we learned and where will they lead us? Endocr Rev 1999;20:358417.

Durkee TJ, Mueller M, Zinaman M. Identification of estrogen receptor protein and messenger ribonucleic acid in human spermatozoa. Am J Obstet Gynecol 2001;178:1288-97.

Fisher JS, Millar MR, Majdic G, Saunders PTK, Fraser HM. Immunolocalisation of oestrogen receptor- $\alpha$ within the testis and excurrent ducts of the rat and marmoset monkey from perinatal life to adulthood. J Endocrinol 1997;153:485-95.

Genissel C, Levallet J, Carreau S. Regulation of cytochrome P450 aromatase gene expression in adult rat Leydig cells: comparison with estradiol production. J Endocrinol 2001;168: 95-105.

Godowicz B, Bilifska B. Effect of cadmium on androgen level and oxidoreductive enzymes activity in cultured Leydig cells of KP and CBA mice. Folia Histochem Cytobiol 1981;19:197-208.

Hess RA, Bunick D, Lee KH, Bahr J, Taylor JA, Korach KS, Lubahn $D B$. A role of oestrogen in the male reproductive tract. Nature 1997;390:509-12.

Hess RA, Bunick D, Bahr J. Estrogen, its receptors and function in the male reproductive tract- a review. Mol Cell Endocrinol 2001;178:29-38.

Janulis L, Hess RA, Bunick D, Nitta H, Janssen S, Osawa Y, et al. Mouse epididymal sperm contains active P450 aromatase which decreases as sperm traverse the epididymis. J Androl 1996;17:111-6.

Jefferson WN, Couse JF, Banks EP, Korach KS, Newbold RR. Expression of estrogen receptor $\beta$ is developmentally regulated in reproductive tissues of male and female mice. Biol Reprod 2000;62:310-7.

Kotula-Balak M, Slomczynska M, Fraczek B, Bourguiba S, Tabarowski Z, Carreau S, et al. Complementary approaches demonstrate that cellular aromatization in the bank vole testis is related to photoperiod. Eur J Histochem 2003; 47:55-62

Kotula-Balak M, Grzmil P, Styrna J, Bilifska B. Immunodetection of aromatase in mice with a partial deletion in the long arm of the $Y$ chromosome. Acta histochem 2004;106:55-64.

Krzanowska $\mathrm{H}$. Relation between fertilisation rate and penetration of eggs by supplementary spermatozoa in different mouse strains and crosses. J Reprod Fertil 1970;22:199-204.

Krzanowska H, Bilinska B. Number of chromocentres in the nuclei of mouse Sertoli cells in relation to the strain and age of males from puberty to senescence. J Reprod Fertil 2000;118:343-50.

Kuiper GGJM, Carlquist M, Gustafsson JA. Estrogen is a male and female hormone. Sci Med 1998;5:36-45.

Lambard S, Galeraud-Denis I, Bouraima H, Bourguiba S, Chocat A, Carreau S. Expression of aromatase in human ejaculated spermatozoa: a putative marker of motility. Mol Hum Reprod 2003;9:117-24.

Levallet J, Carreau S. Aromatase gene expression in rat testicular cells in vitro. CR Acad Sci (Paris) 1997;320:123-9.

Levallet J, Bilinska B, Mittre H, Genissel C, Fresnel J, Carreau S. Expression and immunolocalization of functional cytochrome P450 aromatase in mature rat testicular cells. Biol Reprod 1998;58:919-26.

Li X, Nokkala E, Yan W, Streng T, Saarinen N, Warri A, et al. Altered structure and function of reproductive organs in transgenic male mice overexpressing human aromatase. Endocrinology $2001 ; 142: 2435-42$.

Nitta H, Bunick D, Hess RA, Janulis L, Newton SC, Millette CF, et al. Germ cells of mouse testis express P450 aromatase. Endocrinology 1993;132:1396-1401.

Mahato D, Goulding EH, Korach KS, Eddy EM Estrogen receptor-• is required by the supporting somatic cells for spermatogenesis. Mol Cell Endocrinol 2001;178:57-63.

Makinen S, Makela S, Weihua Z, Warner M, Rosenlund B, Salmi S, et al. Localization of oestrogen receptors alpha and beta in human testis. Mol Hum Reprod 2001;7:497-503.
Mowa CN, Iwanaga T. Expression of estrogen receptor- $\alpha$ and- $\beta$ mRNAs in the male reproductive system of the rat as revealed by in situ hybridization. J Mol Endocrinol 2001;26:165-74.

O'Donnell L, Robertson KM, Jones ME, Simpson ER. Estrogen and spermatogenesis. Endocr Rev 2001;22:289-318.

Papie M, Gancarczyk M, Bilinska B. The compounds from the hollyhock extract (Althaea rosea Cav. var. nigra) affect the aromatization in rat testicular cells in vivo and in vitro. Folia Histochem Cytobiol 2002;40:353-9.

Pelletier G, El-Alfy M. Immunocytochemical localization of estrogen receptors alpha and beta in the human reproductive organs. J Clin Endocrinol Metab 2000;85:4835-40.

Rago V, Bilinska B, Palma A, Ando S, Carpino A. Evidence of aromatase localization in cytoplasmic droplet of human immature ejaculated spermatozoa. Folia Histochem. Cytobiol 2003;41:23-7.

Rosenfeld CS, Ganjam VK, Taylor JA, Yuan X, Gstiehr JR, Hardy JP, et al. Transcription and translation of estrogen receptor- $\beta$ in the male reproductive tract of estrogen receptor- $\alpha$ knock-out and wild-type mice. Endocrinology 1998;139:2982-7.

Saunders PTK, Fisher JS, Sharpe RM, Millar MR. Expression of oestrogen receptor beta (ER beta) in multiple cell types, including some germ cells, in the rat testis. J Endocrinol 1998; 156:R13-R17.

Saunders PTK, Sharpe RM, Willliams K, Macpherson S, Urquart H, Irvine DS, et al. Differential expression of oestrogen receptor alpha and beta proteins in the testes and male reproductive system of human and non-human primates. Mol Hum Reprod 2001;7:227-36.

Schumacher M, Schafer G, Holstein AF, Hilz H. Rapid isolation of mouse Leydig cells by centrifugation in Percoll density gradients with complete retention of morphological and biochemical integrity. FEBS Lett 1978;91:333-8.

Sharpe RM. The roles of oestrogen in the male. Trends Endocrin Metab 1997;9:371-7.

Styrna J, Krzanowska H. Strain differences in sperm quality in mice with different $Y$ chromosome genotype: application of sperm select penetration test. Adv Contra Deliv Syst 1995;11:141-3.

Styrna J, Bilinska B, Krzanowska $H$. The effect of partial $Y$ chromosome deletion in B10.BR-Y ${ }^{\text {del }}$ mice on testis morphology, sperm quality and efficiency of fertilization. Reprod Fertil Dev 2002;14:101-8.

Van Pelt AMM, De Rooij DG, Van Der Burg B, Van Der Saag PT, Gustafsson JA, Kuiper GGJM. Ontogeny of estrogen receptor- $\beta$ expression in rat testis. Endocrinology 1998;140:478-83.

Wu N, Murono EP. Temperature and germ cell regulation of Leydig cell proliferation stimulated by Sertoli cell-secreted mitogenic factor: a possible role in cryptorchidism. Andrologia 1996;28:247-57. 